\title{
The relevance of Intangible Asset, Equity Book, and Earning Value on Stock Price in Information Technology Era
}

\author{
Filosofi Putri Aulia \\ Faculty of Economics and Business \\ Universitas Padjadjaran \\ Poppy Sofia Koeswayo \\ Faculty of Economics and Business \\ Universitas Padjadjaran \\ Djoemarma Bede \\ Faculty of Economics and Business \\ Universitas Padjadjaran
}

\begin{abstract}
This study aims to provide an overview for issuers related to investor's behavior in using the values presented in financial statements in the information technology era, by measuring the moderation effect of intangible assets on the relevance of earnings and book value of equity on stock prices. It tested using a price multiple moderated regression model, and LQ45 indexed issuers on the Indonesia Stock Exchange in 2012 to 2018 as a sample. The results of the study show that investors in the Indonesian capital market use the magnitude of profits and intangible assets as a material for consideration in making investment decisions, and no longer use book value of issuer's equity. They do not entirely switch to using intangible assets as the creator or the principal value of issuers but instead use them as one of the considerations in buying shares of an issuer. However, now investors use the value of intangible assets more dominant than using the value of profits.
\end{abstract}

Keywords: Value Relevance; Intangible Assets; Stock Price; LQ45, Stock Exchange

\section{Introduction}

Financial statements are the most influential media to assess the performance and economic conditions of a company. This financial report is material information for its users in the decision-making process. Nevertheless, claims have been present since the early 1990s related to the diminished use of information in financial statements for investors in the capital market from time to time over the last few decades (Lako, 2007). Investors in the United States Capital Market also only use 3.4\% of financial statement information from all information obtained to assist them in making decisions. 6.2\% comes from analyst estimates, $18.8 \%$ comes from management guidelines, and $71.6 \%$ information comes from various unknown sources such as news in the media, government statistics (Lev, 2013).

The LQ45 PER (price to earnings ratio) in the research period averaged by 19 times, and the PBR (price to book value ratio) averaged by 3,5 times. Both of these ratios indicate that current share prices are too expensive or overvalued by investors. These happen, whether it because current investors become more acceptable to high risk or because investors do not use earnings and book values as a basis for consideration anymore. Nevertheless, a financial statement that can be used in the decision-making process needs to have two main characteristics, namely, reliable and relevant (Martani, 2011). Relevant means that the earnings and book values should have a strong relationship with the stock price 
(Bowerman \& Sharma, 2016). In the Indonesian Capital Market, the relevance level of the book value of equity and the profit value on stock prices of the LQ45 indexed has experienced a downward trend since 2013 with a magnitude of the relevance of $74.7 \%$ to $46.5 \%$ in 2017, with a slight increase to $64,1 \%$ in 2018 .

Some of the researchers' opinions regarding the depreciation of the relevance of the value of accounting information include: that depreciation is caused by massive changes from the industrial economy to high-tech economies and services (Francis \& Schipper, 1999); irrationality investors or inefficient capital markets (Lev, 1989); investor's tendency to use alternative information outside the financial statements as a basis for consideration and decision making in company valuations (Ponziani \& Sukartini, 2008); and the increasing frequency of negative earnings (Collins, Maydew, \& Weiss, 1997).

A new opinion was expressed by Professor Baruch Lev, who suspected the value of intangible assets as the cause of the loss of value relevance in most of the information on financial statements in the US capital market. Nowadays, values are created from ideas and intelligence. The business models of Amazon, Google, Apple, Facebook, and Walt Disney depend on intangible assets (patents, brands, film rights, etc.). Intangible assets become the leading value creators in the current modern economic era (Lev \& Gu, 2016).
In the era of technology and information, now companies are competing to go digital and are starting to pay great attention and appreciation to the value of intangible assets. The value of intangible assets that have been capitalized by the company is also seen positively as the leading creator of the company's value in the eyes of capital market investors (Lev \& Gu, 2016). Thus, the value of most of the accounting information used in financial statements such as earnings (which represents the company's performance) and the book value of equity (which represents the company's financial position) has increasingly shrunk. The relevance or usefulness of these financial statement information for the capital market is now limited.

The presumption of the value of intangible assets as the cause of the declining value relevance of most of the accounting information is also supported by the increasing value of the intangible assets capitalized by the company from time to time. In 2012, LQ45 issuers recorded an average value of intangible assets of IDR 1.3 trillion and continued to increase to IDR 3.7 trillion in 2018. As shown in Figure 1 below, as the value relevance of earnings and the book equity decreases, the value of intangible assets increases. Intangible assets are thought to have diverted the attention of investors in their decision making.

Figure 1. Comparison of Value Relevance of Earnings and Book Equity on Stock Price (in percentage) and Value of Intangible Assets (in Rupiah)

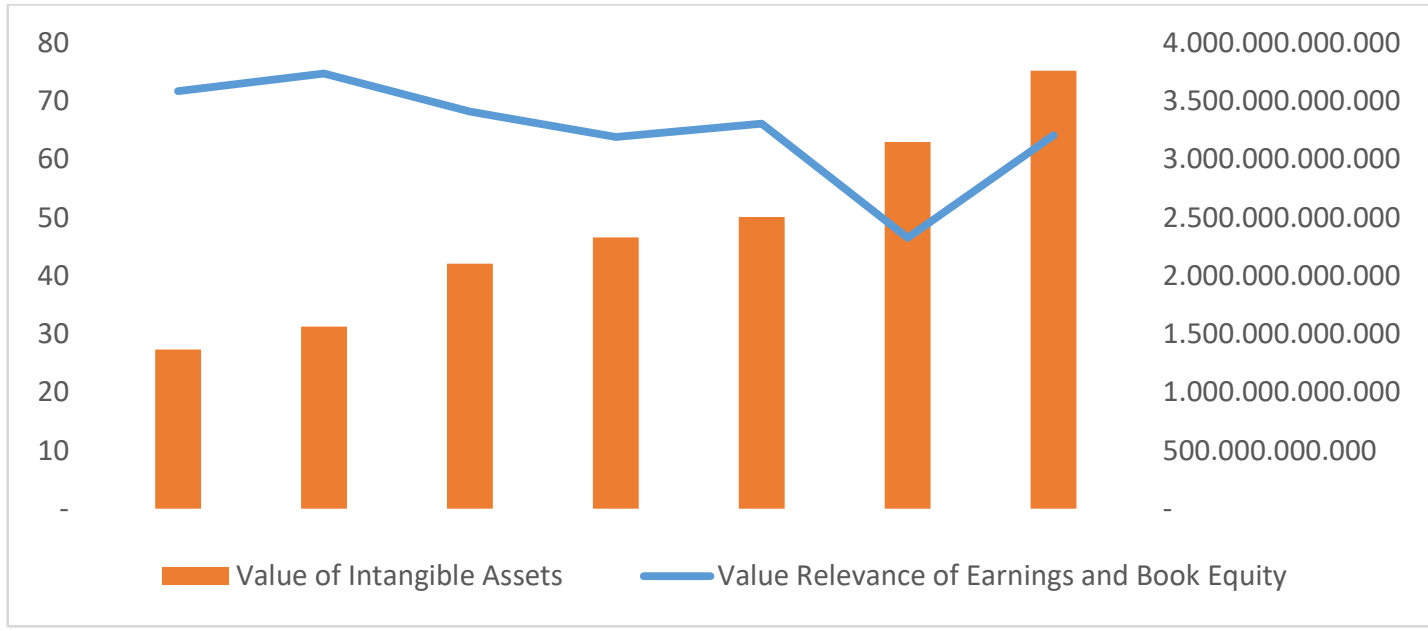


In general, this study aims to provide an overview for issuers related to investor behavior in the capital market in using the values presented in the financial statements, by explaining and measuring the moderation effect of intangible assets on the relevance of accounting information values on stock prices on the Indonesia Stock Exchange. The value of intangible assets is suspected of having significant influence or is associated with the market value of a security in a certain period which has not much been explored before in Indonesia Stock Exchange

Practically, the results of this study are expected to be able to provide an overview for issuers related to investor behavior on the Indonesia Stock Exchange in using the values presented in the issuer's financial statements in making decisions. Theoretically, the results are expected to be a reference and add to the literature in the discussion of the depreciation of the value relevance of accounting information on stock prices on the Indonesia Stock Exchange and the effect of the recognized value of intangible assets in the era of information technology for investors.

\section{Literature Review and Hypothesis Development}

\section{Value Relevance}

The value relevance is defined as the ability of information in financial statements to describe the fundamental value of a company in the capital market (Kargin, 2013). Some also refer it to the usefulness of accounting information, and it is defined as the ability of financial statements information to influence stock prices (Francis \& Schipper, 1999). In statistical language, value relevance can be interpreted as the magnitude of the effect caused by the information in the financial statements on the stock price of the issuer in the capital market. Based on the assumption that a capital market is efficient, statistical measurements are used to determine whether investors use accounting information in making a decision (Ball \&
Brown, 1968). Value relevance studies examine the relationship between accounting information and stock market values (Bowerman \& Sharma, 2016).

\section{Signaling Theory}

Signal theory based on the assumption that information received by management and by the other parties concerned with the information is not the same (information asymmetry). Issuers certainly want to best provide information to public investors about products, financial conditions, and prospects for the issuer's growth to eliminate information asymmetry and make public investors know the issuer better, one of which is through values in the financial statement accounts (et al. Godfrey, 2010). The values presented in the financial statements need to have a high level of relevance in order to be able to provide a signal that illustrates the value of a company well. The book value of equity, the value of earnings, and the value of intangible assets are expected to represent the internal issuers to talk to external parties about the issuer appropriately to help public investors make investment decisions as precisely as possible. Changes in decision making will be reflected in the price and volume of stock trading.

\section{Market Efficiency Theory}

Market Efficiency Theory examines how a market reacts to information to achieve new equilibrium prices because of the entry of new and relevant information into the market. If the market reacts quickly and accurately to reach a new equilibrium price that fully reflects the information available, then this market condition is called an efficient market. Market efficiency is called an information efficiency market, which is how the market reacts to available information (Hartono, 2007). The publication of an annual financial report that provides new information on the book value of equity, profit value, and the value of intangible assets to the market makes investors react, and 
it reflected a new equilibrium price. The efficient market occurred if these values are relevant or had a strong influence on the issuer's stock price.

\section{The book value of equity and Stock prices}

Every issuer on the Indonesia Stock Exchange certainly wants to get a great source of capital from the public by having a high capitalization or value in the market. Issuers publish financial statement information as a signal to attract public investors to invest in it. Financial statements that show the excellent condition of the issuer can attract investors to buy shares of the issuer. A stock that has a higher purchase demand compared to its offer will trigger the stock price to rise, and vice versa, a lower stock demand figure compared to its offer, will trigger the stock price to fall.

Book values and earnings are found to be related positively to stock prices in the Portuguese Stock Exchange (Oliveira, Rodrigues, \& Craig, 2010), Athens Stock Exchange (Iatridis \& Rouvolis, 2010), Australian Securities Exchange (Chalmers, Clinch, \& Godfrey, 2011), Abu Dhabi Securities Market (Khanagha, 2011), Istanbul Stock Exchange (Kargin, 2013), Spanish National Securities Market (Callao, Jarne, \& Laínez, 2007), companies in Germany (Hung \& Subramanyam, 2007); Malaysia (Halim Kadri, Abdul Aziz, \& Kamil Ibrahim, 2010); also United Kingdom (Horton \& Serafeim, 2006).

Investing in an issuer in the long term certainly requires fundamental functional analysis so that investors will not lose their money. Investors will prefer stocks of high book value because the value of equity and large capital values are considered to have the right level of financial stability and have the ability to have better prospects in the future. With a high equity book value, the issuer gives a signal that the issuer has an excellent financial position. Therefore, the authors formulate the hypothesis as follows:

Hypothesis 1: There is a positive effect of the book value of equity on stock prices

\section{Value of earnings and stock prices}

The profit value in the income statement published by the issuer gives a signal to attract public investors to invest in it. Issuers certainly want to provide information to public investors about their performance best to eliminate information asymmetry and make public investors know the issuer better, one of which is through the value of earnings. Investors will prefer shares with a high-value of earnings because it also shows the issuer's excellent performance in its business activities. Issuers in the capital market as a profit-oriented organization will undoubtedly be valued based on the profit or profit gained. With a high-profit value, investors also expect returns from dividends that are also high. Therefore, the authors formulate the hypothesis as follows:

Hypothesis 2: There is a positive effect of the value of earnings on stock prices

\section{Value of Intangible Assets and Stock Price}

In the era of technology and information, now companies are competing to go digital and are starting to pay great attention and appreciation to the value of intangible assets. Many issuers began investing in intangible assets such as patents, goodwill, intellectual property rights, software, skills and knowledge (human capital), brands or brands, research and development (R\&D), artificial intelligence, customer loyalty, and other information technology. The value of intangible assets that have been capitalized by the company will be seen as a creator of corporate value in the information technology era. Reported goodwill and other intangible assets found highly significantly associated with the stock price (Oliveira et al., 2010).

The value of intangible assets tends to have more value in the eyes of consumers (Lev $\& \mathrm{Gu}, 2016)$. Call it a brand, issuers who have a brand that is known by consumers can increase trust and loyalty to the brand. The trust that consumers have in the issuer's products is one of the keys to the success of a business. Savvy stock investors in the capital market will 
also only buy shares of issuers they recognize. Buying shares that are not recognized and are not trusted by its products and business processes are certainly risky stocks. Thus investors will prefer buying shares with intangible assets. Therefore, the authors formulate the hypothesis as follows:

Hypothesis 3: There is a positive effect of the value of intangible assets on the stock price

Value of intangible assets, equity book values, and stock prices

Issuers that have the value of intangible assets provide an attraction for investors. Investors in the US Capital Market are now paying attention to the value of intangible assets. They no longer base their investment decisions on the number of earnings and book value of the issuer's equity, but now begin to use the value of intangible assets as their primary consideration. Intangible assets are now considered to be the leading value creators for issuers on the US capital market.

The same thing happened in the Indonesian capital market where the level of relevance of the decreasing book value of equity is also in line with the increase in the value of intangible assets, raising allegations that investors in the Indonesian capital market also have the same behavioral tendencies with investors in the US capital market. Where now, capital market investors in Indonesia are also paying more attention to the value of intangible assets so that the relevance of earnings value and the book value of equity to share prices is weakening, especially in listed companies of LQ45. Therefore, the authors formulate the hypothesis as follows:

Hypothesis 4: There is a moderating effect on the value of intangible assets to the relationship of equity book values and stock prices

Value of intangible assets, Profit value, and Stock prices

The same condition occurred on the earnings value. The relevance level of its profit value decreases in line with the increase in the value of intangible assets, raising allegations that investors in the Indonesian capital market also have the same behavioral tendencies with investors in the US capital market. Where the capital market investors are now paying more attention to the value of intangible assets so that the relevance of the value of earnings to stock prices has weakened, especially in listed companies LQ45. Therefore, the authors formulate the hypothesis as follows:

Hypothesis 5: There is a moderating effect on the value of intangible assets to the relationship of profit value and stock prices

\section{Methods}

The population in this study are issuers that have been listed in the LQ45 index on the Indonesia Stock Exchange (IDX) from 2012 to 2018. The LQ45 index is a list of the top 45 companies on the IDX with the highest market capitalization and the highest transaction value on the regular market during the year. Companies that are on the LQ45 list are often referred to as 'bluechip' or 'first liner' companies that have the best financial conditions and growth prospects, as well as the highest frequency of transactions (actively traded) among other issuers in the market during the period.

The LQ45 index was chosen by considering them as issuers with the highest transaction value and the highest frequency of transactions in the regular stock market for 12 months in every period. The method was done to minimize the risk of low-value relevance to stock prices due to the low stock buying and selling. The year 2012 to 2018 selection of this period is based on the consideration of the adoption of the full convergence of IFRS (International Financial Reporting Standard) to

PSAK (Indonesian Accounting Standards) which is claimed to be able to increase the relevance of accounting information starting in 2012, and also the year is starting to enter the 4.0 industry revolution in Indonesia, which began in late 2011. 
The LQ45 Index List is published twice in a year, namely in February and August. After the sampling process was obtained, 36 listed companies were listed at least ten times from a total of 14 times the IDX published a list of LQ45 indexes during the period. With a total of 36 issuers and a period of 7 years, a total of 252 data were obtained.
Multiple Moderated Regression Analysis (MMRA) or often also called the intersection test, is a unique approach to multiple linear regression in the regression equation containing the intersection element, which used in this research. The following depicted in Table 1 and Table 2 is the model equations and definition, respectively.

Table 1. Model Equation

(1) Pit $+1=\alpha 0+\beta 1$ BVPSit $+\beta 2$ EPSit + eit

(2) $\quad$ Pit $+1=\alpha 0+\beta 1$ BVPSit $+\beta 2$ EPSit $+\beta 3$ LnIAit $+\varepsilon$ it

(3) Pit $+1=\alpha 0+\beta 1$ BVPSit $+\beta 2$ EPSit $+\beta 3$ LnIAit $+\beta 4$ BVPS $*$ LnIAit $+\beta 5$ EPS $*$ LnIAit $+\varepsilon$ it

Table 2. Model Definition

\begin{tabular}{|c|c|c|}
\hline$\alpha$ & $=$ & Intercept \\
\hline$\beta$ & $=$ & Regression coefficient \\
\hline Pit+1 & $=$ & $\begin{array}{l}\text { The average closing price of the company's stock } i \text { on the capital market for } \\
\text { one week after the issuance of the year } t \text { financial statements }\end{array}$ \\
\hline BVPSit & $=$ & The book value of the company's equity per share at the end of the year \\
\hline EPSit & $=$ & Value of earnings per share of company $i$ in year $t$ \\
\hline LnIAit & $=$ & $\begin{array}{l}\text { The value of intangible assets of company } i \text { in year } t \text { is in the form of } \\
\text { natural logarithms }\end{array}$ \\
\hline BVPS*LnIAit & $=$ & $\begin{array}{l}\text { Interaction of book value of equity per share and value of intangible assets } \\
\text { of company } i \text { in year } t\end{array}$ \\
\hline EPS*LnIAit & $=$ & $\begin{array}{l}\text { The interaction of earnings per share and the value of intangible assets of } \\
\text { company } \mathrm{i} \text { in year } \mathrm{t}\end{array}$ \\
\hline
\end{tabular}

The variables contained in this study are summarized in the following table:

Table 3. Operationalization of Research Variables

\begin{tabular}{|c|c|c|c|c|}
\hline Variables & Reference & Definition & Indicator & Scale \\
\hline $\begin{array}{l}\text { Stock Price } \\
\text { (Y) }\end{array}$ & $\begin{array}{l}\text { (James Ohlson, 1995); } \\
\text { (Collins et al., 1997); } \\
\text { (Francis \& } \quad \text { Schipper, } \\
\text { 1999); \& Zarowin, } \\
\text { (Brief \& } \\
\text { 2005); } \\
\text { (Callao et al., 2007); \& } \\
\text { (Hung } \quad \text { \&ung }\end{array}$ & $\begin{array}{l}\text { Prices that occur in the } \\
\text { capital market at certain } \\
\text { times determined by } \\
\text { market participants. This } \\
\text { market value is } \\
\text { determined by the level of } \\
\text { demand and the level of } \\
\text { stock offer. }\end{array}$ & $\begin{array}{l}\text { The average closing } \\
\text { price of shares for one } \\
\text { week after issuing the } \\
\text { annual financial } \\
\text { statements of each } \\
\text { issuer }\end{array}$ & Ratio \\
\hline $\begin{array}{l}\text { Book Value of } \\
\text { Equity } \\
\text { (X1) }\end{array}$ & $\begin{array}{l}\text { Subramanyam, 2007); } \\
\text { (Chalmers et al., 2011); } \\
\text { (Khanagha, 2011); } \\
\text { (Kargin, 2013); } \\
\text { (Cahyonowati \& } \\
\text { Ratmono, 2013); \& } \\
\text { (Suprihatin } \\
\text { Tresnaningsih, 2016); }\end{array}$ & $\begin{array}{l}\text { Issuer's net asset value or } \\
\text { the value that will be } \\
\text { obtained by the } \\
\text { shareholders if the issuer } \\
\text { goes bankrupt and is } \\
\text { liquidated. }\end{array}$ & $\begin{array}{l}\text { BVPS = Total equity } \\
\text { attributable } \\
\begin{array}{l}\text { owners/number } \\
\text { ordinary } \\
\text { outstanding }\end{array}\end{array}$ & Ratio \\
\hline
\end{tabular}




\begin{tabular}{|c|c|c|c|c|}
\hline $\begin{array}{l}\text { Earning Value } \\
(\mathrm{X} 2)\end{array}$ & $\begin{array}{l}\text { (Badu \& Appiah, } \\
\text { 2018); }\end{array}$ & $\begin{array}{l}\text { Measuring performance } \\
\text { or issuer's performance. } \\
\text { Profits minus burdens. }\end{array}$ & $\begin{array}{l}\text { EPS }=\text { Net profit } \\
\text { attributable to owners } \\
\text { of the parent/number } \\
\text { of ordinary shares } \\
\text { outstanding }\end{array}$ & Ratio \\
\hline $\begin{array}{l}\text { Intangible Asset } \\
\text { Value } \\
\text { (X3) }\end{array}$ & $\begin{array}{l}\text { (Aboody \& Lev, 1998); } \\
\text { (J. Godfrey \& Koh, } \\
\text { 2001); (Bugeja \& } \\
\text { Gallery, } \\
\text { (Oliveira, 2006); } \\
\text { Rodrigues, \& } r \text { Craiga } \\
\text { 2006); (Oliveira et al., } \\
\text { 2010); (Vafaei, Taylor, } \\
\text { \& Ahmed, 2011); (Lev } \\
\text { \& Gu, 2016) }\end{array}$ & $\begin{array}{l}\text { Non-monetary assets that } \\
\text { have the following } \\
\text { characteristics: (1) can be } \\
\text { identified without } \\
\text { physical appearance; (2) } \\
\text { it can be controlled, (3) } \\
\text { and has economic } \\
\text { benefits in the future. }\end{array}$ & $\begin{array}{l}\text { The natural logarithm } \\
\text { of the total value of } \\
\text { intangible assets is } \\
\text { recorded in the } \\
\text { issuer's financial } \\
\text { statements (including } \\
\text { goodwill) }\end{array}$ & Ratio \\
\hline
\end{tabular}

\section{Results}

\section{Variable Performances}

The BVPS performance of each sample issuer represents share ownership in the company per share. BVPS is the amount that will be received by investors (per share) after all the company's assets have been liquidated and paid in full. Analysts commonly use BVPS as a tool to assess the financial health of a company. Investors certainly like a considerable BVPS value, and reject a negative BVPS value because it is considered risky.
On average, the book value of LQ45 share on the IDX has an upward trend. The average BVPS in 2012, which amounted to Rp2,026 per share, increased up to 2018 to reach Rp3,284 per share, as shown in Table 4. The highest BVPS value from the average by issuers is in the banking sector, tobacco, manufacturing, and cement, while issuers valued the lowest BVPS in the property and real estate and the pharmaceutical manufacturing companies.

Table 4. Variable Performances on Average (In Rupiah)

\begin{tabular}{lllllllllll}
\hline & $\mathbf{2 0 1 2}$ & $\mathbf{2 0 1 3}$ & $\mathbf{2 0 1 4}$ & $\mathbf{2 0 1 5}$ & $\mathbf{2 0 1 6}$ & $\mathbf{2 0 1 7}$ & $\mathbf{2 0 1 8}$ & Min & Max & Mean \\
\hline Stock Price & 8,190 & 8,000 & 8,525 & 8,822 & 8,369 & 8,767 & 8,852 & 5,858 & 11,362 & 8,504 \\
\hline BVPS & 2,026 & 2,248 & 2,555 & 2,816 & 3,181 & 3,036 & 3,284 & 1,871 & 3,682 & 2,735 \\
\hline EPS & 434 & 414 & 465 & 405 & 451 & 441 & 481 & 239 & 653 & 442 \\
\hline $\begin{array}{l}\text { Intangible } \\
\text { Assets } \\
\text { (Trillion) }\end{array}$ & $1.36 \mathrm{~T}$ & $1.56 \mathrm{~T}$ & $2.10 \mathrm{~T}$ & $2.32 \mathrm{~T}$ & $2.50 \mathrm{~T}$ & $3.14 \mathrm{~T}$ & $3.75 \mathrm{~T}$ & & & $2.39 \mathrm{~T}$ \\
\hline
\end{tabular}

While BVPS values increase fairly consistent, EPS values increase with quite extreme fluctuations, as shown in Table 4 with an average value of Rp442. The LQ45 issuer's EPS value on average experienced the highest increase in 2014 of Rp51 per share and the lowest decline in 2015 of Rp60 per share. The highest EPS values are owned by tobacco manufacturers, cement, wholesale, and plantation. Similar to the BVPS value, the lowest EPS value is also owned by issuers from the property and real estate, pharmaceutical manufacturing, and telecommunications companies. Figure 2 below is a graph comparing the trends of BVPS and EPS during the study period. 
Figure 2. Comparison of BVPS and EPS of IDX-LQ45 Issuers Year 2012 - 2018 (in Rupiah)

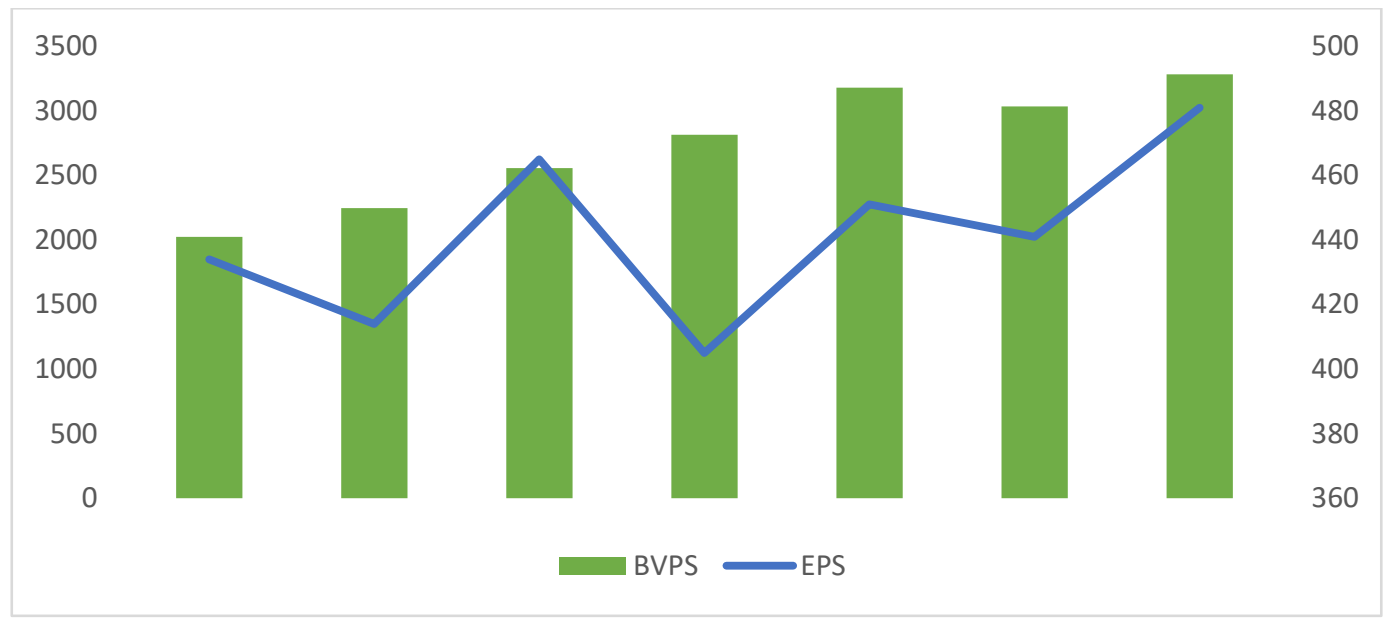

The stock price values also increase with quite extreme fluctuations, as shown in Table 4, with an average value of Rp8,504. LQ45 issuers' stock prices in the study period tended to be worth much higher than the book value of equity per share (BVPS). It indicates that the prices of LQ45 issuers' shares in the capital market have been overvalued. However, the prices prevailing in the capital market often cannot be matched with the value of BVPS because the value in the market is determined by investors' perceptions of the issuer's future and the level of demand and supply in the market.

As stated in the introduction part, the intangible assets value of LQ45 is increasing consistently with an average value of $\mathrm{Rp} 2.39$ trillion during seven periods and continue. Nevertheless, the bookkeeping of Intangible Assets in the financial statements is indeed not carried out by all issuers on the Indonesia Stock Exchange. Issuers listed in the LQ45 index are not always admitted and recorded the value of
Intangible Assets. All samples in the study, which is 36 issuers in total, there were at least eight issuers that did not record the value of intangible assets in their annual financial statements during 2012 - 2018. The eight issuers included: BBNI (PT Bank Negara Indonesia (Persero) Tbk), BBRI (PT Bank Rakyat Indonesia (Persero) Tbk), and BBTN (PT Bank Tabungan Negara (Persero) Tbk) from the banking subsector; GGRM (Gudang Garam Tbk) from the tobacco manufacturing subsector; INCO (Vale Indonesia Tbk) from the metal and mineral mining subsector; LSIP (PP London Sumatra Indonesia Tbk) from the plantation subsector; ASRI (Alam Sutera Realty Tbk) from the property and real estate subsector; and ADHI (PT Adhi Karya (Persero) Tbk) from the building construction subsector.

\section{Variable Influences}

The calculation results of the regression coefficient are shown in Table 5.

Table 5. The Coefficient Estimate Results

\begin{tabular}{clcc}
\hline $\begin{array}{c}\text { Regression } \\
\text { Model }\end{array}$ & \multicolumn{1}{c}{ Independent Variable } & $\begin{array}{c}\text { Coefficient } \\
\text { Estimate }\end{array}$ & $\begin{array}{c}\text { t- } \\
\text { Statistic }\end{array}$ \\
\hline 1st Model & BVPS (Equity Book Value / $\beta 1)$ & $-3,328 \mathrm{E}-5$ & 0,350 \\
& EPS (Earning Value / $\beta 2$ ) & 0,002 & 0,000 \\
\cline { 2 - 4 } 2nd Model & BVPS (Equity Book Value / $\beta 1)$ & $-2,745 \mathrm{E}-5$ & 0,416 \\
& EPS (Earning Value / $\beta 2$ ) & 0,002 & 0,000 \\
& LnIA (Intangible Asset Value / $\beta 3$ ) & 0,019 & 0,000 \\
\cline { 2 - 5 } 3rd Model & BVPS (Equity Book Value / $\beta 1)$ & $-3,317 \mathrm{E}-5$ & 0,675 \\
\hline
\end{tabular}




\begin{tabular}{lcc} 
EPS (Earning Value / $\beta 2$ ) & 0,002 & 0,000 \\
LnIA (Intangible Asset Value / $\beta 3$ ) & 0,013 & 0,005 \\
BVPS*LnIA (Interaction Equity Book and Intangible Asset & $1,005 \mathrm{E}-6$ & 0,761 \\
Value / $\beta 4$ ) & & \\
\hline $\begin{array}{l}\text { EPS*LnIA (Interaction Earning and Intangible Asset Value } \\
\text { / } \beta 5 \text { ) }\end{array}$ & $8,546 \mathrm{E}-6$ & 0,657 \\
\end{tabular}

The calculation results of the regression coefficient $\beta 1$ in the first regression model show a significance probability (sig) of 0.350 . This sig number when compared to the alpha level used which is $5 \%$ or 0.005 with one tail, is so much higher than the regression coefficient. $\beta 1$ is not equal to 0 , so does for the $\beta 1$ in the second and third models. It means that the book value of equity does not affect price changes stock, it gives no influence, or we can say that the book equity is not relevant for investors. It means that most investors do not pay attention and do not use the book value of equity as a basis for consideration of investment decision making on LQ45 indexed listed companies. In other words, the magnitude of book equity is not useful for Indonesian investors in terms of stock market decision making.

Different results on earnings seen from regression coefficient $\beta 2$ in the first model (same result for the second and third model) show a significance probability (sig) of 0.000 . This sig number when compared to the alpha level used $5 \%$ with one tail, is much smaller so that the regression coefficient $\beta 2=0.002$ is very real. It means that every $\mathrm{Rp} 1$ increase in profit value increases the issuer's stock price by $\mathrm{Rp} 0.002$. The results show that investors' choice of LQ45 shares was triggered by changes in the value of the issuer's earnings. Earnings value indeed influences stock prices. It is also relevant and useful for investors. Investors pay attention and use earnings value as a basis for consideration of investment decision making. The increase in profits is undoubtedly considered as good news for investors, triggering investors to buy shares of the issuer.

There are previous researches which gave the same result, namely Halim Kadri, Abdul Aziz, \& Kamil Ibrahim (2010) at Bursa Malaysia; Kargin (2013) on the Istanbul Stock
Exchange; (Iatridis \& Rouvolis, 2010) on the Athens Stock Exchange; Callao, Jarne, \& Laínez (2007) in the Spanish National Securities Market; Hung \& Subramanyam (2007) on the German Stock Exchange; Chalmers, Clinch, \& Godfrey (2011) on the Australian Securities Exchange; Khanagha (2011) at Abu Dhabi Securities Market; also Suprihatin \& Tresnaningsih (2016) on the Indonesia Stock Exchange.

The regression coefficient $\beta 3$ from the 2nd regression model also shows a significance probability (sig) of 0.000 which is smaller compared with the alpha level used, so the regression coefficient $\beta 3=0.019$ is very real. It means that every Rp1 increase in the value of intangible assets increases the issuer's stock price by $\mathrm{Rp} 0.019$. The results also indicate that Indonesian capital market investors pay attention and use the value of intangible assets a consideration for making investment decisions. The interesting thing is that the influence exerted by the value of intangible assets valued at 0.019 is greater than the effect exerted by the profit value of 0.002 . It supported by the results of research by (J. Godfrey \& Koh (2001) and Bugeja \& Gallery (2006) on the Australia Stock Exchange; Oliveira, Lima Rodrigues, \& Craig (2006) on the Portuguese Stock Exchange; and Aboody \& Lev (1998) in the United States Capital Market. A positive and significant effect is obtained between the amount of Intangible Assets value on stock prices in the Capital Market.

The third regression model is performed to see whether the value of intangible assets can provide a moderation effect on the relevance of the book value of equity and the value of earnings to stock prices. In this regression model, the author only pays attention to the coefficient value of the intersection variable, 
namely: the BVPS * LnIA variable which is the multiplication of the book value variable and the intangible asset value; and EPS * LnIA variable which is the multiplication of the variable value of earnings and intangible asset values. Both of these intersection variables proximate the moderation effect of the intangible asset variable with the variable book value of equity and profit value.

The calculation results of the regression coefficient $\beta 4$ and $\beta 5$ show a significance probability (sig) of 0.761 and 0.657 respectively. This sig number is much more significant when compared with the alpha level used $5 \%$ so that the regression coefficient $\beta 4$ and $\beta 5$ are not real or equal to 0 . The results of the study show that there is no moderating effect of intangible assets on the relevance of the book value of equity and the earning value. It indicates that the behavior of investors in Indonesia is not the same as the behavior of investors in the United States who are turning their attention to the value of intangible assets compared to the value of earnings and the book value of the issuer's equity. The reason for the diminishing relevance of the book value of equity and the relevance of the profit value in Indonesia is not the value of intangible assets.

\section{Variable Contributions}

Analysis of the coefficient of determination used for knowing the magnitude contribution of the independent variables on the dependent variable. Analysis of the coefficient of determination is simultaneously shown by the value of R-Square, to see the contribution of the influence given by EPS and BVPS to stock price $(\mathrm{P})$ and when being moderated by the value of Intangible Assets. The results of the analysis of the coefficient of determination simultaneously in this study are shown through the results, as in Table 6 .

Table 6. The R Square Values for Regression Models

\begin{tabular}{ll}
\hline Regression Model & R Square \\
\hline 1st Regression Model & 0,588 \\
2nd Regression Model & 0,631 \\
3rd Regression Model & 0,638 \\
\hline
\end{tabular}

A simultaneous coefficient of determination ( $\mathrm{R}$ Square) value of 0.588 is obtained or equal to $58.8 \%$ in the 1 st regression model. This magnitude shows that changes in the two input variables, namely book value of equity per share (which represents issuer's financial position) and earnings value per share (which represents issuer's performance), contributed $58.8 \%$ to changes in stock price while another $41.2 \%$ is influenced by other factors not observed in this study.

In the second regression model, R Square results obtained 0.631 or equal to $63.1 \%$, which means changes in the three input variables, namely book value of equity, profit value, and value of intangible assets, contribute $63.1 \%$ to changes in stock prices. The increase in the value of R Square in the 2nd regression model shows that the value of intangible assets has a considerable contribution to changes in stock prices.

Furthermore, in the third regression model, R Square results obtained of 0.638 or equal to $63.8 \%$. The increase in the amount of $\mathrm{R}$ Square in the third regression model, which is very small. It is due to the effect of intangible assets as a moderating variable that is not significant in the equation.

\section{Conclusions}

The book value of equity is not relevant and not useful anymore for Indonesian investors on the stock exchange. Most investors use and pay attention to the earning value and more to intangible value as a basis for consideration of their investment decision making, specifically 
for LQ45. The value of intangible assets is indeed the center of attention of investors in consideration of investment in the era of technology and information, and investors are interested in issuers who have high intangible asset values. However, the value of intangible assets is not necessarily a significant consideration of investors in the Indonesian capital market. The reason for the diminishing relevance of the book value of equity and the relevance of the profit value in Indonesia is not because investors value intangible assets like in the US.

\section{References}

Aboody, D., \& Lev, B. (1998). The Value Relevance of Intangibles. Journal of Accounting Research, 36(1998), 161191.

Badu, B., \& Appiah, K. O. (2018). Value Relevance of Accounting Information: An Emerging Country Perspective. Journal of Accounting and Organizational Change, 14(4), 473-491. https://doi.org/10.1108/JAOC-07-20170064

Bowerman, S., \& Sharma, U. (2016). The effect of corporate social responsibility disclosures on share prices in Japan and the UK. Corporate Ownership and Control, 13(2CONT1), 202-216. https://doi.org/10.22495/cocv13i2c1p2

Brief, R. P., \& Zarowin, P. (2005). The Value Relevance of Dividends, Book Value and Earnings. SSRN Electronic Journal. https://doi.org/10.2139/ssrn.173629

Bugeja, M., \& Gallery, N. (2006). Is older goodwill value relevant? Accounting and Finance, 46(4), 519-535. https://doi.org/10.1111/j.1467629X.2006.00181.x

Cahyonowati, N., \& Ratmono, D. (2013). Adopsi IFRS dan Relevansi Nilai Informasi Akuntansi. Jurnal Akuntansi Dan Keuangan, 14(2), 105-115. https://doi.org/10.9744/jak.14.2.105-115

Callao, S., Jarne, J. I., \& Laínez, J. A. (2007). Adoption of IFRS in Spain: Effect on the comparability and relevance of financial reporting. Journal of International Accounting, Auditing and Taxation, 16(2), 148-178. https://doi.org/10.1016/j.intaccaudtax.20 07.06.002

Chalmers, K., Clinch, G., \& Godfrey, J. M. (2011). Changes in value relevance of accounting information upon IFRS adoption: Evidence from Australia. Australian Journal of Management, 36(2), 151-173. https://doi.org/10.1177/03128962114045 71

Collins, D. W., Maydew, E. L., \& Weiss, I. S. (1997). Changes in the value relevance of earnings and book values over the past forty years. Journal of Accounting and Economics, 24(1), 39-67. https://doi.org/10.1016/S01654101(97)00015-3

Francis, J., \& Schipper, K. (1999). Have Financial Statements Lost Their Relevance? Journal of Accounting Research, 37(2), 319-352. https://doi.org/10.2469/dig.v30.n3.703

Godfrey, et. al. (2010). Accounting Theory (7th ed.). Australia: John Wiley \& Sons Australia, Ltd.

Godfrey, J., \& Koh, P. (2001). The Relevance to Firm Valuation of Capitalising Intangible Assets in Total and by Category. Australian Accounting Review, 11(2), 39-48.

Halim Kadri, M., Abdul Aziz, R., \& Kamil Ibrahim, M. (2010). Value Relevance of Book Value and Earnings: Evidence from Two Different Financial Reporting Regimes. Journal of Financial Reporting and Accounting, 7(1), 1-16. https://doi.org/10.1108/19852510980000 638

Hartono, J. (Gadjah M. U. (2007). Portfolio Theory and Investment Analysis (Teori Portofolio dan Analisis Investasi). Yogyakarta, Indonesia: BPFE UGM.

Horton, J., \& Serafeim, G. (2006). Market Response To and The Value Relevance of Reconciliation Adjustments from UK GAAP to IFRS GAAP: First Evidence 
from the UK.

Hung, M., \& Subramanyam, K. R. (2007). Financial statement effects of adopting international accounting standards: The case of Germany. Review of Accounting Studies, 12(4), 623-657. https://doi.org/10.1007/s11142-0079049-9

Iatridis, G., \& Rouvolis, S. (2010). The postadoption effects of the implementation of International Financial Reporting Standards in Greece. Journal of International Accounting, Auditing and Taxation, 19(1), 55-65.

https://doi.org/10.1016/j.intaccaudtax.20 09.12 .004

James Ohlson. (1995). Earnings, book values, and dividends in equity valuation. Contemporary Accounting Research, 11(11), 661-687.

Kargin, S. (2013). The Impact of IFRS on the Value Relevance of Accounting Information: Evidence from Turkish Firms. International Journal of Economics and Finance, 5(4), 71-80. https://doi.org/10.5539/ijef.v5n4p71

Khanagha, J. B. (2011). Value Relevance of Accounting Information in the United Arab Emirates. International Journal of Economics and Financial Issues, 1(2), 33-45.

Lako, A. (2007). Relevansi nilai informasi akuntansi untuk pasar saham: problema dan peluang riset. Jurnal Akuntansi \& Manajemen, 8(2), 1-31.

Lev, B. (1989). On the Usefulness of Earnings and Earnings Research: Lessons and Directions from Two Decades of Empirical Research. Journal of Accounting Research, Current Studies on The Information Content of Accounting Earnings, 27(3), 153-192. https://doi.org/10.1006/bare.1999.0101

Lev, B. (2013). The End of Accounting and What' S Next?

Lev, B., \& Gu, F. (2016). The End of Accounting and the Path Forward for Investors and Managers. Hoboken, New Jersey: John Wiley \& Sons, Inc.
Martani, D. (Indonesia U. (2011). Akutansi dan Akuntabilitas: Esai Pemikiran. Jakarta, Indonesia: Salemba Empat.

Oliveira, L., Lima Rodrigues, L., \& Craig, R. (2006). Firm-specific determinants of intangibles reporting: evidence from the Portuguese stock market. Journal of Human Resource Costing \& Accounting, 10(1), 11-33.

https://doi.org/10.1108/14013380610672 657

Oliveira, L., Rodrigues, L. L., \& Craig, R. (2010). Intangible assets and value relevance: Evidence from the Portuguese stock exchange. British Accounting Review, 42(4), 241-252. https://doi.org/10.1016/j.bar.2010.08.001

Ponziani, R. M., \& Sukartini. (2008). Relevansi Nilai Informasi Akuntansi: Sintesis Penelitian Empiris di Berbagai Negara. Jurnal Akuntansi \& Manajemen ISSN 1858-3687, 3(2), 33-45.

Suprihatin, S., \& Tresnaningsih, E. (2016). Dampak Konvergensi International Financial Reporting Standards Terhadap Nilai Relevan Informasi Akuntansi. Jurnal Akuntansi Dan Keuangan Indonesia, 10(2), 171-183. https://doi.org/10.21002/jaki.2013.09

Vafaei, A., Taylor, D., \& Ahmed, K. (2011). The value relevance of intellectual capital disclosures. Journal of Intellectual Capital, 12(3), 407-429. https://doi.org/10.1108/14691931111154 